\title{
Burnout Syndrome and Quality of Life in Nursing Professors of a Public University
}

\begin{abstract}
Sérgio Ribeiro dos Santos ${ }^{1}$, Leila de Cássia Tavares da Fonsêca ${ }^{2}$, Eveline de Oliveira Barros ${ }^{3}$, Jaqueline Brito Vidal Batista4, Mary Sandra Carlotto ${ }^{5}$, Ericka Silva Holmes ${ }^{6}$
\end{abstract}

\section{Abstract}

Objective: Characterize the socio-demographic conditions of nursing professors, evaluate the burnout syndrome, check the perception of quality of life, and analyze the quality of life of these professionals according to the physical, psychological, social relationships, and environment.

Method: This is a study of exploratory, descriptive and quantitative approach, which analyzed 35 professors of a nursing course. For this it was used the CESQT and the WHOQOL-BREF tools. Data were analyzed using descriptive statistics.

Results: 4 professors were identified (11.43\%) with high level, 9 (25.71\%) with an medium level, 15 (42.86\%) with low, and 6 (17.14\%) with very low symptoms of burnout. The quality of life, their perception about it, and satisfaction with health were classified as regular.

Conclusion: It is necessary to strengthen the measures that can prevent the burnout syndrome and study strategies to face this problem in academia.
1 Nurse. PhD Professor of Department of Clinical (DENC/CCS/UFPB) and a Professor in the Graduate Program in Nursing (PPGENF/CCS/UFPB). Brazil.

2 Nurse. PhD student at the PostGraduate Nursing in Federal University of Paraíba. Brazil.

3 Nurse. Master's Graduate Program in Nursing at the Federal University of Paraiba (PPGEnf/UFPB). JP-PB*.

4 Psychologist. PhD Adjunct Professor of the Federal University of Paraíba Education Center and a Professor in the Graduate Program in Nursing (PPGENF/ CCS/UFPB). Brazil.

5 Psychologist, PhD in Social Psychology from the University of Santiago de Compostela and professor in the Department of Psychology at ULBRA

6 Nurse. PhD student at the PostGraduate Decision Models and Health Federal University of Paraíba. Brazil.

*: João Pessoa, Paraiba, Brazil.

\section{Contact information:}

\section{Ericka Silva Holmes.}

” ericka_holmes@hotmail.com

\section{Keywords}

Burnout; Occupational mealth; Professors; Quality of Life.
Work as a way of fulfillment for humans has been investigated by many researchers as Dejours [1], Antunes [2], Motter; Grigorio; Antonio [3], Fialkoski; Meneghetti; Rangel [4], Glanzner; Olschowsky; Kantorki [5], Diehl; Carlotto [6]. The labor activity itself is not the cause of illnesses, however under specific conditions it can be the source for many problems that compromise the worker's health and interfere in the quality of the work as well as in the quality of life. Researches 
give a special attention to this since occupational diseases can affect all the social levels [7].

Education as the main tool for professionals' formation, regarding higher education level, is going through paradigmatic crises. These require professor to have technical and scientific skills that are not only limited to the applicability of the knowledge, but that pervade the knowledge and involve social relationships in order to know how to do and to be. In this perspective, nursing education is connected to the health system, in which the pedagogical phenomena happen through a complex relation in real life, that goes beyond the relationship between professor and students, involving patients and their relatives. [8]

Higher education in Brazil has many flaws, ranging from poor academic formation that can be said to happen due to low salaries, work condition and low professional recognition, which comes from historic derogatory and have been degrading the physical installations of the universities, paving the way for privatizing the higher education and exploitation of the teaching work. This leads to situations of emotional pressure and arises cases of psychosomatic illnesses, and "malaise lecture", which comes from globalization and neoliberal adjustment policy which has its main methodology for defining educational policies based on economy. Consequently this influences the work process and the management of higher education. [9]

Considering the numerous health problems which can come from the university professor's job, a good attention is done to burnout syndrome or SB. Burnout is not a recent phenomenon; it was first described in the 1970's and several studies about it have been published. Studies on the prevalence showed a predominance of it in workers form human sciences and health, specially: nurses, doctors, social workers, and professors since those are in constant contact with students. [10-11, 6]

The figure of the professor came under the tutelage of the church, between the fifteenth and six- teenth centuries in order to provide reading for the people. The origin of this profession has its meaning based on professing the faith: people who give themselves priestly to students. In the beginning this profession incorporated many privileges with high qualification and autonomy, located in the field of intellectual work, opposing manual labor, and nowadays this professions is seen discredited and devalued. [12]

Nowadays professors are highly assessed for their failures and have low recognition when they succeed. They work mentally and emotionally overwhelmed and their work expose them to stress factors that might lead to the development of burnout syndrome. [13]

Besides being more accepted, the Maslach and Jackson instrument has presented psychometric shortcomings when adapted to other languages, which led to adaptation and validation to Brazil of a Spanish instrument used to evaluate the burnout syndrome in the education professionals, "Cuestionario para la Evolución del Síndrome de Quemarsepor el trabajo -CESQT". [14]

The CESQT considers four dimensions: the illusion for the work, which is expectance in achieving professional targets; psychological exhaustion (as the presence of physical and emotional exhaustion); indolence, considered as negative attitudes of indifference to others, and a fourth dimension, the blame. This tool considers the burnout syndrome as a response to chronic job stress, developed in professionals that work directly with people. [14-15]

Being a professor is considered by the International Labour Organization, as one of the most stressful professions, with high incidence of elements that lead to the SB, and therefore a high-risk profession, considered as the second professional category worldwide to have occupational diseases. [16] Thus, the health of the professor has been a source of concerns to various segments of the society, since this phenomenon affects professors from 
different countries, arising worldwide epidemically and going beyond national borders. $[13,17]$

Within the reality of teaching work, it is found higher education professors. In the current scenario they have a workload that goes beyond the requirements regarding the higher education tripod: teaching, research and society-related projects. This workplace (university) requires a lot of involvement from the worker, that includes publications, participation in boards, mentoring undergraduate programs, tutoring and specific planning of all these activities. They also face other conditions in the workplace, such as stress and work organization, which the professors are submitted. Constantly this professional does not find subsidies neither physical nor operational to achieve the job expectations, allowing stress, helplessness and frustration to have influence in their work process and health. $[7,18]$

An interesting point about this subject is the possibility of investigating the level of impairment of health of nursing professors, the influence of burnout syndrome in their quality of life, and how this can impact the health of professors in the present and future. Considering the above mentioned, it is sought the answer for the following question: Is there a real possibility of the Burnout syndrome to affect the nursing professors working at the Federal University of Paraíba? What perception nursing professors have about their quality of life? How they evaluate the quality of life considering physical, psychological, social relationships, and environment fields?

Therefore, this study aims: characterize the sociodemographic conditions of nursing professors from a public university; to assess the burnout syndrome in nursing professors; check the perception of quality of life of nursing professors; analyze the quality of life of nursing professors according to physical, psychological, social relationships and environment fields.

\section{Method}

This study is exploratory, descriptive and has a quantitative approach. Thirty-five professors of the course in Bachelor Degree in Nursing at the Federal University of Paraíba were submitted to this test. All of them work at the Health Sciences Center and Departments of Clinical Nursing, and Public Health Nursing and Psychiatry of the institution above mentioned.

Three self-applicable instruments were used: CESQT (describe it) and WHOQOL-BREF, a tool developed and validated by the Study Group on Quality of Life belOging to World Health Organization, Mental Health Division - WHOQOL Group. The other instrument was a questionnaire with questions social, economic and professional, to characterize the sample profile.

The CESQT has 20 items, which are distributed in four dimensions or subscales, named as: a) illusion for the work, composed of 5 items; b) psychic wear, composed of 4 items; c) Indolence, 6 items; and d) blame composed of 5 items. In order to answer the items presented in each subscale, the question sheet has a frequency scale varying from 0 (never), 1 (Rarely), 2 (Sometimes: a few times a month), 3 (Frequently), and 4 (Everyday).

The theoretical model in which CESQT is based on considers four dimensions (as above mentioned), however, the fourth dimension which is the feeling of blame, only appears after the three other dimensions and is not necessarily developed in all individuals, generating two profiles. The profile 1, which excludes the blame, generates a moderate form of discomfort, but do not unable the professor of working; and the profile 2 which includes the feeling of blame. [14]

It is important to mention that the calculations for identifying the burnout syndrome were done according to the CESQT Manual. [15] which establishes five levels of burnout: critical, high, medium, low and very low. Yet it was considered the PD values, where low scores for "illusion at work" (<2) and 
high scores for "psychic wear" ( $\geq 2)$, might indicate high levels of burnout.

In order to classify the professors within profiles one or two, it was considered that profile two has full SQT percentile (classified as critical or high), plus high blame/fault level. Whereas profile one includes the ones with full SQT percentile (classified as critical or high) but have not had a high blame/fault level. (Gil-Monte, 2011).

It was calculated Cronbach's alpha for each domain presented by burnout and the total SQT. Cronbach's alpha coefficient is used to measure the internal accuracy of a measuring instrument; it can vary from 0 to 1 , and values close to 0 (zero) indicate lower accuracy, whereas values close to 1 indicate high consistency on the test. [19]

The WHOQOL-bref was validated by the World Health Organization (WHO) and consists of 26 questions; two of them are about general points of quality of life (1- Perception of quality of life; 2 - Satisfaction with health) and each of the remaining 24 represent the 24 facets that make up the original instrument. Different from WHOQOL-100 in which each of the 24 facets is evaluated considering 4 questions, in the WHOQOL-bref every facet is evaluated by only one question which is multiple choice, and the answers are based on Likert scale, ranging from 1 (Nothing), 2 ( Very low), 3 (Medium), 4 (Quite/A lot), to 5 (Completely). The questions are easy to response, and aim to assess the quality of life.

Thus, the 24 facets are divided into 4 areas: 1Physical(pain and discomfort; energy and fatigue; sleep and rest; mobility; daily activities, dependence of medication or treatment, work capacity); 2 - Psychological (positive feelings, thinking, learning, memory and concentration, self-esteem, body image and appearance; negative feelings, spirituality /religion /personal beliefs); 3 - Social relationships (personal relationsships; social support, sexual activity); 4 - Environment (physical security and protection; home environment; financial resources; health and social care: availability and quality; opportunities to acquire new information and skills, opportunity for recreation/leisure, physical environment - pollution /noise/traffic /weather, transport).

Besides the above mentioned, it is presented the results of the areas ranging from 4 to 20 and from 0 to 100 . It should be considered that the closer to 20 or 100 , respectively, the result is, the better the evaluations of the domain is.

It is important to point out that the implementation of this research followed the ethical principles inherent in researches involving humans, such as: anonymity, respect for the person, maximum guarantee of individual and community benefits, and equal consideration of the interests involved, as required by Resolution ${ }^{\circ} 466 / 12$, form the National Health Council, in force in the country. This study was approved by the Research Ethics Committee from the Health Sciences Centre of the Federal University of Paraíba with CAEE $\mathrm{n}^{\circ}$ 50611115.1.0000.5188.

\section{Results}

The public taken for this study contains predominantly feminine: 31 females (88.6\%), 22 of them (62.9\%) are married, and each of the 31 (88.6\%) have children. The number of children ranges from 1 to 4 . Most of them have income between 5 to 10 minimum wages. Considering the education, 28 (80\%) of them have doctorate, and most of them, 30 (85.7\%) (Table 1), work full time. The ages of the participants range from 33 to 66 years, with mean age equal to 49.5 years $(S D=9.32$ ). Regarding how long they have been working at UFPB, the average time was 22.4 years $(S D=11.23)$.

Considering extra activities other than teaching, 9 (25.7\%) professors have other academic obligations, which include: managing departments, research and society-related projects at the University Hospital, pedagogic coordination, and administrative division (Table 1). The biggest part of them - 34 
Table 1. Description of demographic and labor data of nursing professors UFPB, João Pessoa, 2016.

\begin{tabular}{|c|c|c|}
\hline Variables & $n$ & $\%$ \\
\hline \multicolumn{3}{|l|}{ Gender } \\
\hline Feminine & 31 & 88.6 \\
\hline Masculine & 04 & 11.4 \\
\hline \multicolumn{3}{|l|}{ Gender } \\
\hline Not married & 05 & 14.3 \\
\hline Married & 22 & 62.9 \\
\hline Divorced & 06 & 17.1 \\
\hline \multicolumn{3}{|l|}{ Children } \\
\hline Yes & 31 & 88.6 \\
\hline No & 04 & 11.4 \\
\hline \multicolumn{3}{|l|}{ Income (salary) } \\
\hline$<5$ & 01 & 2.9 \\
\hline$>5$ a 10 & 14 & 40 \\
\hline$>10$ a 20 & 08 & 22.9 \\
\hline$>20$ & 12 & 34.2 \\
\hline \multicolumn{3}{|l|}{ Titration } \\
\hline Specialization & 0 & 0 \\
\hline Master & 07 & 20 \\
\hline Postdoctoral & 28 & 80 \\
\hline $\mathrm{PhD}$ & 0 & 0 \\
\hline \multicolumn{3}{|l|}{ Regime work } \\
\hline $\mathrm{T}-20$ & 01 & 2.9 \\
\hline $\mathrm{T}-40$ & 04 & 11.4 \\
\hline $\mathrm{DE}$ & 30 & 85.7 \\
\hline \multicolumn{3}{|l|}{ Another function } \\
\hline Yes & 09 & 27 \\
\hline No & 26 & 74.3 \\
\hline
\end{tabular}

(97.1\%)- works exclusively for UFPB, while only 1 (2.9\%) professor has a second job. Regarding the work shift, all professors work in morning and afternoon, and only 2 (5.7\%) of them have activities on the night shift.

Regarding the data from the CESQT, it was observed the average of the subscales (direct scores) and then it was done a classification of cases having apparent symptoms of Burnout, according to Table 2. One individual (2.9\%) was found to have critical burnout symptoms; 4 (11.43\%) professors have high level; 9 (25.71\%) have medium level; 15 (42.86\%) have low level; and 6 (17.14\%) have a very low level of symptoms for Burnout.

For the construction of profiles 1 and 2, it was used the values of the direct scores and their respective percentile. Thus the professor is rated as profile 2 if he/she has a high level of total SQT as well as high levels for blame. Five (14.3\%) professors were found to have their blame subscale altered to/ for high or critical. with the subscale changed blame for high or critical level. However, only 2 (5.7\%) of these also showed high levels of total SQT, and therefore could be considered within profile 2 (SQT modified to higher or critical plus blame altered to high). Three (8.6\%) professors which have shown alteration of total SQT for high or critical were identified as profile 1, according table 2 .

It was also calculated the mean value (average), the standard deviation and Cronbach's alpha of the dimensions of the burnout syndrome, in order to prove the internal consistency of the data and

Table 2. Ratings Direct (PSD) subscales of the SBI, according to the nursing faculty. João Pessoa-PB, 2016

\begin{tabular}{|c|c|c|c|c|c|c|}
\hline $\mathbf{N}^{\circ}$ & Illusion at work & $\begin{array}{c}\text { Psychological } \\
\text { exhaustion }\end{array}$ & Indolence & Blame* & SQT total & $\begin{array}{c}\text { Classification } \\
\text { SQT }\end{array}$ \\
\hline 1 & 3 & 2.25 & 1 & 0.4 & 1.33 & High \\
\hline 2 & 4 & 1 & 0 & 0.2 & 0.27 & Very Low \\
\hline 3 & 3.8 & 2 & 1.17 & 2.2 & 1.07 & Medium \\
\hline 4 & 4 & 0.25 & 0.5 & 0.4 & 0.27 & Very Low \\
\hline 5 & 4 & 0.75 & 0.17 & 0 & 0.27 & Very Low \\
\hline 6 & 3.8 & 1 & 0.5 & 0.6 & 0.53 & Low \\
\hline
\end{tabular}




\begin{tabular}{|c|c|c|c|c|c|c|}
\hline $\mathbf{N}^{\circ}$ & Illusion at work & $\begin{array}{l}\text { Psychological } \\
\text { exhaustion }\end{array}$ & Indolence & Blame* & SQT total & $\begin{array}{c}\text { Classification } \\
\text { SQT }\end{array}$ \\
\hline 7 & 3.2 & 0.5 & 0.33 & 0.4 & 0.53 & Low \\
\hline 8 & 4 & 1.25 & 0.33 & 0.8 & 0.46 & Low \\
\hline 9 & 4 & 1 & 1.17 & 1 & 0.73 & Medium \\
\hline 10 & 3.6 & 1 & 0.33 & 1 & 0.53 & Low \\
\hline 11 & 3.2 & 1 & 0.17 & 1.2 & 0.6 & Low \\
\hline 12 & 3.8 & 1.75 & 1.17 & 0.4 & 1 & Medium \\
\hline 13 & 4 & 3.25 & 0.83 & 1.8 & 1.2 & Medium \\
\hline 14 & 3.6 & 2 & 0.83 & 0.6 & 1 & Medium \\
\hline 15 & 3.8 & 1.75 & 0.17 & 0.8 & 0.6 & Low \\
\hline 16 & 3 & 1.5 & 0.67 & 0.8 & 1 & Medium \\
\hline 17 & 4 & 1.75 & 0 & 1 & 0.46 & Low \\
\hline 18 & 2.8 & 2.75 & 0.67 & 1.6 & 1.4 & High \\
\hline 19 & 4 & 0.75 & 0.5 & 1 & 0.4 & Low \\
\hline 20 & 4 & 0.5 & 0.83 & 0.4 & 0.46 & Low \\
\hline 21 & 3 & 2 & 1.33 & 1.6 & 1.4 & High \\
\hline 22 & 3 & 2 & 1 & 1 & 1.27 & Medium \\
\hline 23 & 4 & 0 & 0.33 & 0.2 & 0.13 & Very Low \\
\hline 24 & 3.2 & 2 & 0.83 & 1.4 & 1.13 & Medium \\
\hline 25 & 3.2 & 0.5 & 0.17 & 0.4 & 0.46 & Low \\
\hline 26 & 3 & 3 & 1.5 & 0.2 & 1.73 & High \\
\hline 27 & 3.8 & 1.25 & 0.83 & 1 & 0.73 & Medium \\
\hline 28 & 3.6 & 0 & 0.17 & 0.4 & 0.2 & Very Low \\
\hline 29 & 3.8 & 0.75 & 0.67 & 1.2 & 0.53 & Low \\
\hline 30 & 2.4 & 2 & 1.83 & 0.8 & 1.8 & Critical \\
\hline 31 & 3.2 & 0.75 & 0.33 & 0.6 & 0.6 & Low \\
\hline 32 & 4 & 0.75 & 0.67 & 1 & 0.46 & Low \\
\hline 33 & 4 & 0.75 & 0.17 & 0.4 & 0.27 & Very Low \\
\hline 34 & 4 & 0.25 & 1 & 0.8 & 0.46 & Low \\
\hline 35 & 3.8 & 1.75 & 0.33 & 0.4 & 0.67 & Low \\
\hline
\end{tabular}

Source: Research Source: research data, 2016. * Note: the fault component was not used to perform the classification by the total SQT, but to rank in Profile 1 or Profile 2.

ensure that they are significantly related to the original constructs to evaluate facets of SB, as seen in table 3.

In order to characterize the sample in study considering the classification of each dimension, it was built table 4 , where is possible to identify the percentages for each dimension and their classification. Thirteen $(37.43 \%)$ cases of "psychic wear" with mid-level were identified; 18 (51.43\%) were diagnosed with medium level for "indolence", and 17 (48.57\%) with "blame".

Considering the quality of life, it was observed in table $\mathbf{5}$ that the main domain is the Domain 2 (psychological domain), with higher ranking, have an avarage of 4.13 (good), and its facet 6 (thinking, learning, memory and concentration) was the one that obtained the highest average within this domain ( $M=4.69$; good). The Domain 4 (environment) 
Table 3. Mean, standard deviation and internal consistency (Cronbach's alpha) of SBI dimensions. João Pessoa-PB, 2016

\begin{tabular}{|l|c|c|c|}
\hline & Average & Standard deviation & Cronbach's alpha \\
\hline Illusion at work & 3.59 & 0.45 & 0.79 \\
\hline Psychological exhaustion & 1.31 & 0.83 & 0.84 \\
\hline Indolence & 0.67 & 0.45 & 0.70 \\
\hline Fault & 0.80 & 0.50 & 0.67 \\
\hline CESQT (15 Items)* & 0.74 & 0.44 & 0.71 \\
\hline
\end{tabular}

Source: Research data, 2016. * Note: questions regarding the components illusion at work, Psychological exhaustion and Indolence.

Table 4 Frequency and percentage of the four components of burnout syndrome. João Pessoa-PB, 2016.

\begin{tabular}{|l|c|c|c|c|c|}
\multicolumn{1}{c|}{ Classification } & Verylow & Low & Avarage & High & Critical \\
\cline { 2 - 7 } & $\mathrm{P} \leq 11$ & $\mathrm{P} 11-33$ & $\mathrm{P} 34-66$ & $\mathrm{P} 67-89$ & $\mathrm{P} \geq 90$ \\
\hline Illusion at work & - & $02(5.7 \%)$ & $20(57.14 \%)$ & $13(37.14)$ & - \\
\hline Psychological exhaustion & $07(20 \%)$ & $12(34.29 \%)$ & $13(37.43 \%)$ & $02(5.7 \%)$ & $01(2.9 \%)$ \\
\hline Indolence & $02(5.7 \%)$ & $12(34.29 \%)$ & $18(51.43 \%)$ & $02(5.7 \%)$ & $01(2.9 \%)$ \\
\hline Fault & $01(2.9 \%)$ & $12(34.29 \%)$ & $17(48.57 \%)$ & $03(8.57 \%)$ & $02(5.7 \%)$ \\
\hline
\end{tabular}

Source: Research data, 2016.

Table 5. Means domains and facets of WHOQOL-brefquestionnaire. João Pessoa-PB, 2016.

\begin{tabular}{|c|c|c|}
\hline Characteristics & M & Classification \\
\hline 1. Perception of quality of life & 3.91 & Regular \\
\hline 2. Satisfaction with health & 3.74 & Regular \\
\hline Domain 1: Physical Domain & 3.98 & Regular \\
\hline 3. Pain and discomfort & 4.09 & Good \\
\hline 4. Energy and fatigue & 3.66 & Regular \\
\hline 10. Sleep and rest & 3.86 & Regular \\
\hline 15. Mobility & 4.69 & Good \\
\hline 16. Activity of daily life & 3.29 & Regular \\
\hline $\begin{array}{l}\text { 17. Medication dependency } \\
\text { or treatments }\end{array}$ & 4.09 & Good \\
\hline 18. Working capacity & 4.17 & Good \\
\hline $\begin{array}{l}\text { Domain 2: Psychological } \\
\text { domain }\end{array}$ & 4.13 & Good \\
\hline 5. Positive feelings & 3.71 & Regular \\
\hline $\begin{array}{l}\text { 6. Thinking, learning, memory } \\
\text { and concentration }\end{array}$ & 4.69 & Good \\
\hline 7. Self-esteem & 3.91 & Regular \\
\hline $\begin{array}{l}\text { 11. Body image and } \\
\text { appearance }\end{array}$ & 4.17 & Good \\
\hline 19. Negative feelings & 4.26 & Good \\
\hline $\begin{array}{l}\text { 26. Spirituality/religion/ } \\
\text { personal beliefs }\end{array}$ & 4.03 & Good \\
\hline
\end{tabular}

\begin{tabular}{l|c|c|}
\hline Characteristics & M & Classification \\
\hline Domain 3: Social Relations & 4.06 & Good \\
\hline $\begin{array}{l}\text { 20. Personal relationships } \\
\text { 21. Support Social }\end{array}$ & 4.14 & $\begin{array}{c}\text { Good } \\
\text { Regular }\end{array}$ \\
\hline $\begin{array}{l}\text { 22. Sexual activity } \\
\text { Domain 4: Environment }\end{array}$ & 3.94 & Good \\
\hline $\begin{array}{l}\text { 8. Physical security and } \\
\text { protection }\end{array}$ & 3.74 & Regular \\
\hline $\begin{array}{l}\text { 9. Home environment } \\
\text { 12. Financial resources }\end{array}$ & 3.49 & Regular \\
\hline $\begin{array}{l}\text { 13. Health and social care: } \\
\text { availability and quality }\end{array}$ & 3.34 & Regular \\
\hline $\begin{array}{l}\text { 14. Opportunities to acquire } \\
\text { new information and skills }\end{array}$ & 3.11 & Regular \\
\hline $\begin{array}{l}\text { 23. Participation in, } \\
\text { and recreation /leisure } \\
\text { opportunity }\end{array}$ & 4.43 & Regular \\
\hline $\begin{array}{l}\text { 24. Physical environment: } \\
\text { (pollution/noise/traffic/ } \\
\text { weather) }\end{array}$ & 3.37 & Rood \\
\hline 25. Transport & 4.43 & Source: research data, 2016. \\
\hline
\end{tabular}


had the worst average among the other domains ( $M=3.74)$ and was classified as "regular", and its facet 14 (Opportunities for acquiring new information and skills) was the one that got lower mean/ avarage within this domain ( $\mathrm{M}=3.11$; "Regular").

It is important to point out that for the domains ita was calculates the mean/average of the scores, following the scales ranging between 4-20 and $0-100$, according guidelines available in the manual. The averages of the scale can be seen in table 6 .

Table 6. Mean number of 4-20 and 0-100 of the scores of quality of life domains (WHOQOLbref) on a scale of 4-20. João Pessoa-PB, 2016.

\begin{tabular}{|l|c|c|}
\hline \multicolumn{1}{|c|}{ Domains } & Average 4-20 & Average 0-100 \\
\hline Physicist & 15.92 & $\mathbf{7 4 . 5 0}$ \\
\hline Psychological & 16.52 & 78.25 \\
\hline Social relationships & 16.54 & 76.50 \\
\hline Environment & 14.96 & 68.50 \\
\hline \multicolumn{2}{|c|}{ Source: Research data, 2016. }
\end{tabular}

\section{Discussion}

The burnout syndrome has been impacting negatively the teaching-learning process, the educational environment, and educational targets, as well as in the organizational climate of the workplace and in the physical and mental health of the worker. [11] This study characterized social and demographic conditions, assessed the SB and the perception of quality of life of nursing faculty.

Besides being professor it is important to mention that some professionals have accumulated positions and activities other than teaching; the number of activities to be done and the time spent for that is overwhelming these professionals. Thus, one can infer that the academic demands which involve teaching, research and society-related projects, in addition to demands for publications (required for having functional progression), and proof of the activities developed in a regular basis, lead to psycho- logical pressure, which makes them a target for the development of emotional stress. [20-21]

This study shows that 20 (85.7\%) professors work under the exclusive dedication regime (40 hours per week). This fact does not exclude who work in T-20 and $\mathrm{T}-40$ regimes of being demanded for deep involvement with the academy, and likely become victims of the stress surrounding them.

According to the criteria established and validated by the CESQT (2011), it was found from table 2 that $5(14.3 \%)$ of the evaluated professors show symptoms of burnout; 3 of them (8.6\%) belong to profile 1 . This situation is worrying and confirms the results presented in the study of Costa et al. [22], in which $19(11.2 \%)$ of university professors were found to be as profile 1 and 5 (3\%) profile 2 .

It was also observed that $2(5,7 \%)$ professors have percentile compatible with cases belonging to profile 2, which express the association of symptoms of burnout with the fourth dimension found by GilMonte [15-22], the "blame". According to Costa et al. [22], professors with burnout present cognitive and affective deterioration characterized as loss of motivation for working and emotional exhaustion or mental wear; some of them also develop behaviors of coldness and detachment; in some cases, the blame comes after all the symptoms listed above, however not all individuals develop it.

From table 2, it was seen that 9 (25.71\%) patients were considered to have a "medium" level risk to the development of BS. This result concerns the academy about the profile of professors, which are likely to move to the high or critical level of this pathology. Batista et al. [17], argue that the presence of moderate cases is worry since lack of knowledge about SB as well as its diagnosis, persists among workers and doctors.

Other authors claim the importance of prevention, because studies indicate that the lack of diagnosis helps the development of this syndrome; if the identification this syndrome is not done it can be aggravated, since its symptoms can be trivialized 
or confused with stress or even depression, which can be a comorbidity of burnout, depending on the clinical picture; This is unfortunate, because the lack of knowledge leads to late diagnosis [16-23].

It is important to point out that there is a cognitive impairment that is related to the loss of motivation, with a low personal fulfillment at work, which is the result of an illusion and a chronic exhaustion caused by accumulation of stress. Gradually individuals perform negative attitudes towards students and the institution, which is precisely the manifestation of indolence, coldness and detachment towards others, followed by blame or not. [22]

A work done by Costa et al. [22], found that the excessive workload, conflicts and ambiguities of positions, conflicts in relationship with students and other professors, and the lack of support are the main reasons for the development of SB. Gil-Monte [15] argues that unfavorable psychosocial factors at work, such as stress, can lead to a poor quality of life at work and negative consequences for the health and welfare.

The data analysis conducted with the WHOQOLbref instrument could identify the classification of domains and their respective facets. Thus, the answers show that professors realize they have "regular" quality of life and satisfaction with health. These results differ from found by Machado et al. [24], in which professors showed their quality of life and satisfaction with the health of $81 \%$ and $77.2 \%$, respectively.

The workers' quality of life and satisfaction with the health will make them motivated professionals, who will produce more and will contribute to the development of a more humane and just society [25]. The questions about the quality of life from the instrument rate four domains: physical, psychological, social and environmental. The present study had the worst scores for the physical and environmental areas, obtaining a "medium" grade.

Specifically for the physical domain, the results indicate that professors believe that energy and fa- tigue due to work, as well as daily activities, sleep, and rest are negatively affected. Regarding the environmental domain, the following facets are compromised: physical security and protection, home environment, financial resources, health and social care, opportunities to acquire new information and skills, and the physical environment, because of pollution, noise, traffic and weather. These results do not agree with the study done by Conceição et al.26, which identified for the environmental domain the scores "enough", "very" and "satisfied" as $69.4 \%$ of the responses.

Both psychological (mean/avarage $=4.13$ ) and social relations domains (mean $=4.06$ ) were classified as "good". Note that for the psychological domain, the quality of life is investigated through the pursuit for positive feelings related to thinking, memory, concentration, self-esteem, learning, concentration and body image. Whereas the field of social relations involve friendships, family relationships, social support and sexual activity. [26]

Thus, it can be inferred that the assessment of quality of life through the four domains presented helped to detect some vulnerable aspects (facets) in the nursing faculty, which indicate the need for changes that meet the reality experienced by these professionals, since themselves evaluate the overall as regular. The environmental domain must be considered, since it is strictly related to working conditions, and how healthy physical environment is (questioned the facet 9), but still taking in account all the other facets that build up the WHOQOL-BREF questionnaire. [26-27]

\section{Conclusions}

It is clear the importance of evaluating the Burnout Syndrome and the quality of life of nursing professors of a public university. In this work it was used two instruments validated in Brazil; the " $i$ CESQT$P E^{\prime \prime}$, evaluates the burnout syndrome in professional related to education, and it takes in account four 
dimensions: the illusion at work, psychic wear, indolence and blame, differing from the Malasch Burnout Inventory; whereas the WHOQOL-bref quantify the quality of life, since symptoms of the disease can be related to it; it is important to mention that daily problems faced by professors at work can influence their quality of life

This study obtained similar results to studies that also investigated the SB. It was proved that some nursing professors tend to develop the SB; regarding the quality of life, it was found that the nursing professors consider it as regular. The WHOQOL-bref scored in the four domains: physical, psychological, social and environmental. In this study, the physical and environment domains were the ones who had the lowest scores, rated as "medium".

It is important to point out that this study is a part of doctoral thesis entitled "burnout syndrome in professors teaching in health related area: impact on quality of life". Note that is was neither performed an inferential analysis nor correlation test, due to limitation on the sample size, which was specific the graduate faculty of two nursing departments of the Public University of Paraiba.

Thus, the results draw attention in order to strengthen measures that can prevent the SB, and to plan strategies to fight this problem in the universities. For achieving this it is necessary let people know about this syndrome. Despite being a disease recognized and typified by the Ministry of Social Welfare, many professionals and managers still do not know about it; this reinforces the need for more research focused on this subject in order to bring effective measures for fighting it and then succeed as a professional. The outcome of achieving it will be a better quality in education and improvement on management, avoiding time away from work or even early retirement due to health problems caused by the work.

\section{References}

1. Dejours C. A loucura do trabalho. Cortez-Oboré, São Paulo, 1992.

2. Antunes R. Adeus ao Trabalho? Ensaio sobre as metamorfoses e a centralidade no mundo do trabalho. 2011. 15. ed. São Paulo: Cortez.

3. Motter AA, Grigório JM, Antonio NKSM. Atividade docente em uma universidade pública brasileira: prazer ou sofrimento no trabalho? InternationalJournalonWorkingConditions, 2015; 9(n).

4. Fialkoski AC, Meneghetti TV, Rangel FB.A Carga Psíquica No Trabalho: o trabalho como fonte de sofrimento ou prazer. XI Salão de Iniciação Científica PUCRS. 2010.

5. Glanzner CHG, Olschowsky A, KantorkiLP. O trabalho como fonte de prazer: avaliação da equipe de um Centro de Atenção Psicossocial. RevEscEnferm USP 2011; 45(3):716-21

6. Diehl L, Carlotto MS. Conhecimento de professores sobre a síndrome de burnout: processo, fatores de risco e consequências1. Psicologia em Estudo, Maringá. 2014. 19(4): 741-752.

7. Sousa MC, Guimarães ACA, Araújo CCR. Estresse no trabalho em professores universitários. Revista Brasileira de Ciências da Saúde. 2013, 11(35).

8. Pinhel I,Kurcgant P. Reflexões sobre competência docente no ensino de enfermagem. Revista da Escola de Enfermagem da USP. 2007; 41(4): 711-716.

9. Lima MFEM,Lima-Filho DO. Condições de trabalho e saúde do/a professor/a universitário/a. Ciências \& Cognição; 2009; 14(3):62-82.

10. Garcia LP, Benevides-Pereira AMT. Investigando o burnoutem professores universitários. Revista Eletrônica InterAçãoPsy - Ano 1. 2003; v.(1): 76-89.

11. Carlotto MS. A Síndrome de Burnout e o trabalho docente. Psicologia em Estudo, Maringá. 2002; 7(1): 21-29.

12. Valente GSC,Viana LO. Oensino de nivel superior no Brasil e as competências docentes: um olhar reflexivo sobre esta prática. Práxis Educacional. Vitória da Conquista. 2010; 6(9): 209-226.

13. Carlotto MS. Síndrome de Burnout em Professores: Prevalência e Fatores Associados. Psicologia: Teoria e Pesquisa.2011; 27(4):403-410.

14. Gil-Monte PR, Carlotto MS, Câmara SG. Validación de laversiónbrasileradelCuestionario para laEvaluacióndel Síndrome de Quemarse por elTrabajoen professores. Rev. Saúde Pública. 2010; 44(1):140-147.

15. Gil-Monte, P. R. CESQT. Cuestionario para laevaluacióndel Síndrome de Quemarse por elTrabajo. 2011; Manual. Madrid, España: TEA.

16. Brasil. Ministério da Saúde. Organização Pan-Americana da Saúde/Brasil. Doenças Relacionadas ao Trabalho: manual de procedimentos para os serviços de saúde. Série A. Normas e Manuais Técnicos. Brasília - DF. 2001;114p. 
17. Batista JBV et al . Prevalência da Síndrome de Burnout e fatores sociodemográficos e laborais em professores de escolas municipais da cidade de João Pessoa, PB. Rev. bras. epidemiol., São Paulo; 2010; 13(3).

18. Duarte NS, Mauro MY. Análise dos fatores de risco ocupacionais do trabalho de enfermagem sob a ótica dos enfermeiros. Revista Brasileira de Saúde Ocupacional. 2010; 35(121).

19. Anjos A, Andrade DF. Teoria da Resposta ao Item com uso do R. 2012.

20. Barreto MA. Docência Universitária: Condições de Trabalho, Estresse e Estratégias de Enfrentamento. XXXII Encontro da ANPAD. Rio de Janeiro. 2008.

21. Hoppy YN. Estresse Ocupacional: percepção de colaboradores de uma instituição de ensino superior. Centro Universitário UNIVATES. 2012. [Monografia].

22. Costa LST, et al. Prevalência da Síndrome de Burnout em uma Amostra de Professores Universitários Brasileiros. Psicologia: Reflexão e Crítica. 2013; 26 (4), 636-642.

23. Gil-Monte PR. The influence of guilt on the relationship between burnout and depression. EuropeanPsychologist. 2012; 17; 231 236.

24. Machado EL et al. Qualidade de vida dos docentes: um estudo de caso. Revista da Universidade Vale do Rio Verde, Três Corações. 2011; 9(2): 255-263.

25. Teixeira CS. Qualidade de vida do trabalhador: discussão conceitual. Revista Digital - Buenos Aires - Año 14. 2009; v(136) p.

26. Conceição MR et al. Qualidade de vida do enfermeiro no trabalho docente: estudo com o whoqol-bref. Esc Anna Nery (impr.) $2012 \mathrm{abr}$-jun; 16 (2):320- 325.

27. Koetz L, Rempel C, Périco E. Qualidade de vida de professores de Instituições de Ensino Superior Comunitárias do Rio Grande do Sul. Ciência \& Saúde Coletiva. 2013; 18(4):1019-1028.
Publish in International Archives of Medicine

International Archives of Medicine is an open access journal publishing articles encompassing all aspects of medical science and clinical practice. IAM is considered a megajournal with independent sections on all areas of medicine. IAM is a really international journal with authors and board members from all around the world. The journal is widely indexed and classified Q1 in category Medicine. 